\title{
TATA KELOLA SIM-RS DALAM PENCEGAHAN KETIDAKLENGKAPAN SENSUS HARIAN RAWAT INAP DI RUMAH SAKIT CIREMAI TINGKAT III 03.06.01 CIREBON
}

\author{
Fikry Tryasmoro ${ }^{1}$, Dwiyanti Purbasari ${ }^{2}$, Rosalia Rahayu $^{3}$ \\ 1,2,3 STIKes Mahardika, Cirebon, Indonesia, fikrytryasmoro99@gmail.com
}

\begin{tabular}{|c|c|}
\hline ARTICLE INFORMATION & $A B S T R A C T$ \\
\hline Received: July, 31, 2021 & The results of a preliminary study conducted at hospital Tingkat III \\
\hline Revised: Agustus, 10, 2021 & 03.06.01 Ciremai Cirebon, that the daily inpatient census form in \\
\hline Available online: September, 10, 2021 & $\begin{array}{l}\text { August } 2020 \text { to December } 2020 \text { there are complete inpatient daily } \\
\text { census forms, namely } 92 \% \text { (1340) and } 8 \%(115) \text { which are incomplete. }\end{array}$ \\
\hline KEYWORDS & $\begin{array}{l}\text { This type research uses quantitative descriptive. The population of this } \\
\text { study were inpatient nurses and midwives, head of inpatient care, head }\end{array}$ \\
\hline $\begin{array}{l}\text { SIM-RS governance, incomplete } \\
\text { census daily inpatient }\end{array}$ & $\begin{array}{l}\text { of inpatient installation, and medical recorders.. The sample technique } \\
\text { uses proportional random sampling. The research instrument used a } \\
\text { questionnaire. The analysis of this study uses univariate analysis. The } \\
\text { research results obtained that the SIM-RS governance in prevention of }\end{array}$ \\
\hline CORRESPONDENCE & incomplete census daily inpatient of appropriate, namely as many as 27 \\
\hline $\begin{array}{l}\text { Fikry Tryasmoro } \\
\text { STIKes Mahardika, Indonesia } \\
\text { E-mail: } \\
\text { fikrytryasmoro99@gmail.com }\end{array}$ & $\begin{array}{l}\text { carrying out the daily inpatient census is appropriate. The human } \\
\text { resources of the SIM-RS installation in carrying out the daily inpatient } \\
\text { census are appropriate. The framework in the SIM-RS installation in } \\
\text { the implementation of the daily inpatient census, namely } 15(41.7 \%) \\
\text { were appropriate. The hospital medical records are strived to improve } \\
\text { coordination, monitoring and evaluation of the management of hospital } \\
\text { management information system relating to the management of the } \\
\text { daily inpatient census with the head of the inpatient installation } \\
\text { periodically. }\end{array}$ \\
\hline
\end{tabular}

\section{A B $\mathbf{S}$ T $\mathbf{R}$ A $\mathbf{K}$}

Hasil studi pendahuluan yang dilakukan di Rumah Sakit Tingkat III 03.06.01 Ciremai Cirebon, bahwa formulir sensus harian rawat inap pada bulan Agustus 2020 sampai dengan Desember 2020 terdapat formulir sensus harian rawat inap yang lengkap yaitu 92\% (1340) dan $8 \%$ (115) yang tidak lengkap. Jenis penelitian ini menggunakan deskriptif kuantitatif. Populasi penelitian ini adalah perawat dan bidan rawat inap, kepala rawat inap, kepala instalasi rawat inap dan perekam medis. Teknik sampel menggunakan proportional random sampling. Instrumen penelitian ini menggunakan kuesioner. Analisis penelitian ini menggunakan analisis univariat. Hasil penelitian diperoleh bahwa tata kelola SIM-RS dalam pencegahan ketidaklengkapan sensus harian rawat inap yang sesuai yaitu $27(75,0)$. Struktur organisasi instalasi SIM-RS dalam pelaksanaan sensus harian rawat inap yang sesuai yaitu $34(94,4 \%)$. SDM instalasi SIM-RS dalam pelaksanaan sensus harian rawat inap yang sesuai yaitu $31(86,1 \%)$. Kerangka kerja instalasi SIMRS dalam pelaksanaan sensus harian rawat inap yaitu $15(41,7 \%)$ yang sesuai. Pihak rekam medis rumah sakit diupayakan agar meningkatkan koordinasi, monitoring dan evaluasi tata kelola SIM-RS yang berkaitan dengan pengelolahan sensus rawat inap dengan kepala instalasi rawat inap secara periodik. 


\section{PENDAHULUAN}

Berdasarkan Peraturan Menteri Kesehatan RI nomor 82 tahun 2013, menjelaskan bahwa sensus harian rawat inap merupakan laporan pada sistem informasi manajemen rawat inap dan laporan internal sistem informasi manajemen rekam medis. Sensus harian rawat inap rumah sakit adalah kegiatan pencacahan atau penghitungan pasien rawat inap yang dilakukan setiap hari pada suatu ruang rawat inap berisi pasien masuk, pasien pindah ruangan, dan pasien keluar selama 24 jam. Sensus harian rawat inap biasanya dilakukan pada waktu tengah malam (pukul 24:00 atau 00:00) atau kapan saja sepanjang waktunya konsisten pada semua unit. Tujuan dilakukannya sensus harian rawat inap adalah untuk memperoleh informasi pasien masuk, pindah ruangan, dan pasien keluar di unit rawat inap selama 24 jam (Hosizah dan Maryati, 2018).

Berdasarkan Standar Nasional Akreditasi Rumah Sakit (2017) bab 6, tentang standar manajemen informasi rekam medis dijelaskan bahwa dalam penyampaian data dan informasi secara akurat, lengkap dan tepat waktu dalam format yang memenuhi kebutuhan laporan untuk membantu dalam pengambilan keputusan rumah sakit. Kriteria standar kelengkapan data-data rekam medis yakni100\% terisi pada semua item atau poin di dalam formulir sensus harian rawat inap.

Rumah sakit memiliki tata kelola dalam penyelenggaraan Sistem Informasi Manajemen Rumah Sakit (SIM-RS). Tata kelola bertujuan dapat membantu rumah sakit untuk tetap fokus terhadap nilai strategis penggunaan SIM-RS dan memastikan penerapan SIM-RS untuk mendukung pencapaian tujuan rumah sakit. (Permenkes, 2013).

Hasil penelitian Suhamad (2015) di Rumah Sakit Umum Pusat Nasional Dr. Cipto Mangkusumo Jakarta, bahwa pada formulir sensus harian rawat inap, di data pasien masuk terdapat 92,15\% lengkap dalam pengisian kolom nomor rekam medis. Pada formulir sensus harian rawat inap, di data pasien keluar terdapat 92,36\% lengkap dalam pengisianya kolom nomor rekam medis. Data autentikasi dalam formulir sensus harian rawat inap terdapat $78,3 \%$ lengkap dalam pengisiannya.

Hasil studi pendahuluan yang dilakukan peneliti di Rumah Sakit Tingkat III 03.06.01 Ciremai Cirebon, bahwa formulir sensus harian rawat inap yang meliputi format data pasien masuk, data pasien pindah ruangan, data pasien keluar dan data autentikasi (tanda tangan, nama ruangan dan tanggal) pada bulan Agustus 2020 terdapat yang lengkap yaitu 89\% (260) dan 11\% (31) yang tidak lengkap, pada bulan September 2020 terdapat formulir sensus harian rawat inap yang lengkap yaitu 94\% (272) dan 6\% (18) yang tidak lengkap, pada bulan Oktober 2020 terdapat formulir sensus harian rawat inap yang lengkap yaitu 96\% (297) dan 4\% (13) yang tidak lengkap, pada bulan November 2020 terdapat formulir sensus harian rawat inap yang lengkap yaitu 95\% (278) dan 5\% (15) yang tidak lengkap, pada bulan Desember 2020 terdapat formulir sensus harian rawat inap yang lengkap yaitu $86 \%$ (233) dan 14\% (38) yang tidak lengkap, dan pada bulan Agustus 2020 sampai dengan Desember 2020 terdapat formulir sensus harian rawat inap yang lengkap yaitu $92 \%$ (1340) dan 8\% (115) yang tidak lengkap. Berdasarkan data tersebut, kelengkapan sensus harian rawat inap mengalami kenaikan dari bulan Agustus sampai dengan Oktober 2020 namun mengalami penurunan pada bulan November dan Desember 2020, hal ini menunjukan adanya perubahan yang belum selaras dengan pencapaian target yaitu $100 \%$.

Menurut hasil wawancara di Rumah Sakit Tingkat III 03.06.01 Ciremai Cirebon dengan petugas rekam medis penanggung jawab rekapitulasi sensus harian rawat inap, diketahui bahwa penyebab ketidaklengkapan pengisian sensus harian rawat inap dikarenakan perawat dan bidan yang diberi tugas untuk mengisi formulir

sensus harian rawat inap memiliki tugas lain sehingga pekerjaan perawat dan bidan tidak hanya fokus pada pengisian sensus harian rawat inap, formulir sensus harian rawat inap yang sudah diisi dan dikumpulkan dari 
masing-masing ruang rawat inap ke instalasi rawat inap langsung dilaporkan ke unit rekam medis pelaksanaan pengisian sensus harian rawat inap masih dilakukan secara manual dengan media kertas, serta belum menerapkan Standar Oprasional Prosedur (SOP) tentang sensus harian rawat inap. Upaya yang dilakukan oleh unit rekam medis yakni akan dilakukan pembuatan SOP sensus harian rawat inap dan pengajukan pembuatan SIM-RS sensus harian rawat inap, namun dalam pembuatan SIM-RS sensus harian rawat inap belum ada tindak lanjut oleh instalasi SIM-RS. Berdasarkan hal tersebut penulis mengambil judul penelitian "Tata Kelola SIM-RS Dalam Pencegahan Ketidaklengkapan Sensus Harian Rawat Inap Di Rumah Sakit Tingkat III 03.06.01 Ciremai Cirebon”.

Tujuan penelitian ini adalah Mengetahui gambaran tata kelola SIM-RS dalam pencegahan ketidaklengkapan sensus harian rawat inap di Rumah Sakit Tingkat III 03.06.01 Ciremai Cirebon

\section{METODE}

Jenis penelitian ini adalah penelitian deskriptif kuantitatif. Variabel dalam penelitian ini yaitu tata kelola SIM-RS dalam pencegahan ketidaklengkapan sensus harian rawat inap. Populasi penelitian ini adalah perawat dan bidan pelaksana sensus harian rawat inap, kepala ruangan rawat inap, kepala instalasi rawat inap, dan perekam medis di Rumah Sakit Tingkat III 03.06.01 Ciremai Cirebon yang berjumlah 39 orang. Teknik pengambilan sampel dalam penelitian ini menggunakan teknik Proportional Random Sampling dengan sampel yang didapatkan yaitu 36 responden. Instrumen pada penelitian ini adalah menggunakan lembar kuesioner yang disusun oleh peneliti berisi pertanyaan tertutup yang berjumlah 22 item dengan pilihan jawaban yang tercantum yaitu "Ada" yang memliki nilai 1 dan "Tidak ada" yang memiliki nilai 0 dengan dilakukan uji instrumen menggunakan uji validitas dan realibilitas dilakukan di Rumah Sakit Umum Daerah Waled Kabupaten Cirebon, Jl. Prabu Kiansantang, Waled Kota, Kecamatan Waled,
Kabupaten Cirebon. Waktu pelaksanaan akan dilakukan pada tanggal 8 Juni-11 Juni 2021 yang didapatkan hasil tiga item soal yang tidak valid dan uji realibilitas dengan nilai Cronbach's Alpha yaitu 0,889. Prosedur pengumpulan data dengan langkah-langkahadalah peneliti melakukan uji etik ke Komisi Etik Penelitian Kesehatan (KEPK) dan mengajukan surat pengantar penelitian dari STIKes Mahardika Cirebon serta menyerahkan surat pengantar penelitian ke kantor Kesatuan Bangsa Politik Dalam Negeri Kota Cirebon dan Direktur Rumah Sakit Tingkat III 03.06.01 Ciremai Cirebon, peneliti meminta bantuan kepada pembimbing lahan penelitian untuk membantu peneliti dalam pengumpulan data pada kuesioner, peneliti melakukan sosialisasi dan pelatihan kepada pembimbing lahan penelitian sebelum melakukan penelitian yang dilakukan dalam waktu satu hari, dan peneliti atau pembimbing lahan penelitian melakukan pengumpulan data kepada responden. Analisis data dalam penelitian ini menggunakan analisis univariat. Penelitian ini dilaksanakan pada tanggal 17 juni - 22 Juni 2021. Penelitian ini di laksanakan di Rumah Sakit Tingkat III 03.06.01 Ciremai Cirebon yang terletak di Jl. Kesambi No.237, Drajat, Kecamatan Kesambi, Kota Cirebon, Jawa Barat .

\section{HASIL PENELITIAN}

Hasil penelitian ini diolah dengan analisis univariat menggunakan software SPSS versi 25 dan hasil yang diperoleh dapat disajikan dalam tabel. 
1. Tata kelola SIM-RS dalam pencegahan ketidaklengkapan sensus harian rawat inap

Tabel 1

Distribusi Frekuensi Responden Berdasarkan Tata

Kelola SIM-RS Dalam Pencegahan Ketidaklengkapan Sensus Harian Rawat Inap Di Rumah Sakit Tingkat III 03.06.01 Ciremai Cirebon $(n=36$ orang; tanggal 1722 Juni 2021)

\begin{tabular}{|l|l|l|}
\hline \multicolumn{1}{|c|}{$\begin{array}{c}\text { Tata Kelola } \\
\text { SIM-RS }\end{array}$} & \multicolumn{1}{c|}{ Frekuensi } & \multicolumn{1}{c|}{ Presentas } \\
\hline Sesuai & 27 & $\mathbf{7 5 , 0 \%}$ \\
\hline Kurang Sesuai & 9 & $\mathbf{2 5 , 0 \%}$ \\
\hline Total & $\mathbf{3 6}$ & $\mathbf{1 0 0 , 0 \%}$ \\
\hline
\end{tabular}

Berdasarkan pada tabel 1 didapatkan 27 responden $(75,0 \%)$ bahwa tata kelola SIM-RS dalam pencegahan ketidaklengkapan sensus harian rawat inap sudah sesuai, dan 9 responden $(25,0 \%)$ adalah kurang sesuai.

2. Struktur organisasi instalasi SIM-RS dalam pelaksanaan sensus harian rawat inap di Rumah Sakit Tingkat III 03.06.01 Ciremai Cirebon

\section{Tabel 2}

Distribusi Frekuensi Responden Berdasarkan Struktur Organisasi Instalasi SIM-RS Dalam Pelaksanaan Sensus Harian Rawat Inap Di Rumah Sakit Tingkat III 03.06.01 Ciremai Cirebon $(n=36$ orang; tanggal 17-22 Juni 2021)

\begin{tabular}{|l|c|c|}
\hline $\begin{array}{c}\text { Sruktur } \\
\text { Organisasi SIM- } \\
\text { RS }\end{array}$ & Frekuensi & Presentase \\
\hline Sesuai & 34 & $94,4 \%$ \\
\hline Kurang Sesuai & 2 & $5,6 \%$ \\
\hline Total & $\mathbf{3 6}$ & $\mathbf{1 0 0 , 0 \%}$ \\
\hline
\end{tabular}

Berdasarkan hasil analisa tabel 2 dapat diperoleh 34 responden $(94,4 \%)$ menyatakan bahwa struktur organisasi instalasi SIM-RS dalam pelaksanaan sensus harian rawat inap sudah sesuai, dan 2 responden $(5,6 \%)$ menyatakan bahwa struktur organisasi instalasi SIM-RS dalam pelaksanaan sensus harian rawat inap masih kurang sesuai.

3. Sumber daya manusia instalasi SIM-RS dalam pelaksanaan sensus harian rawat inap di Rumah Sakit Tingkat III 03.06.01 Ciremai Cirebon

Tabel 3

Distribusi Frekuensi Responden Berdasarkan Sumber Daya Manusia Instalasi SIM-RS Dalam Peelaksanaan Sensus Harian Rawat Inap Di Rumah Sakit Tingkat III 03.06.01 Ciremai Cirebon ( $n=36$ orang; tanggal 1722 Juni 2021)

\begin{tabular}{|l|c|c|}
\hline \multicolumn{1}{|c|}{ SDM SIM-RS } & Frekuensi & Presentase \\
\hline Sesuai & 31 & $86,1 \%$ \\
\hline Kurang Sesuai & 5 & $13,9 \%$ \\
\hline Total & $\mathbf{3 6}$ & $\mathbf{1 0 0 , 0 \%}$ \\
\hline
\end{tabular}

Berdasarkan hasil analisa univariat pada tabel 3 didapatkan dari 31 responden $(86,1 \%)$ menyatakan bahwa sumber daya manusia instalasi SIM-RS dalam pelaksanaan sensus harian rawat inap sudah sesuai, dan menyatakan bahwa sumber daya manusia instalasi SIM-RS dalam pelaksanaan sensus harian rawat inap masih kurang sesuai yaitu 5 responden $(13,9 \%)$.

4. Kerangka kerja instalasi SIM-RS dalam pelaksanaan sensus harian rawat inap di Rumah Sakit Tingkat III 03.06.01 Ciremai Cirebon.

\section{Tabel 4}

Distribusi Frekuensi Responden Berdasarkan Kerangka Kerja Instalasi SIM-RS Dalam Pelaksanaan Sensus Harian Rawat Inap Di Rumah Sakit Tingkat III 03.06.01 Ciremai Cirebon $(n=36$ orang; tanggal 17-22 Juni 2021)

\begin{tabular}{|l|c|c|}
\hline $\begin{array}{c}\text { Kerangka Kerja } \\
\text { SIM-RS }\end{array}$ & Frekuensi & Presentase \\
\hline Sesuai & 15 & $41,7 \%$ \\
\hline Kurang Sesuai & 12 & $33,3 \%$ \\
\hline Tidak Sesuai & 9 & $25,0 \%$ \\
\hline Total & $\mathbf{3 6}$ & $\mathbf{1 0 0 , 0 \%}$ \\
\hline
\end{tabular}


Berdasarkan hasil analisa pada 4 dapat diperoleh 15 responden $(41,7 \%)$ menyatakan bahwa kerangka kerja instalasi SIM-RS dalam pelaksanaan sensus harian rawat inap sudah sesuai, 12 responden $(33,3 \%)$ menyatakan bahwa kerangka kerja instalasi SIM-RS dalam pelaksanaan sensus harian rawat inap masih kurang sesuai, dan menyatakan bahwa kerangka kerja instalasi SIM-RS dalam pelaksanaan sensus harian rawat inap masih tidak sesuai yaitu 9 responden $(25,0 \%)$.

\section{PEMBAHASAN}

1. Tata kelola SIM-RS dalam pencegahan ketidaklengkapan sensus harian rawat inap

Hasil penelitian tentang tata kelola SIM-RS dalam pencegahan ketidaklengkapan sensus harian rawat inap di Rumah Sakit Tingkat III 03.06.01 Ciremai Cirebon Tahun 2021 menunjukkan hasil tata kelola SIM-RS dalam pencegahan ketidaklengkapan sensus harian rawat inap sebanyak $27(75,0 \%)$ secara umum termasuk dalam kategori sesuai. Berdasarkan pengamatan peneliti terhadap kuesioner yang telah diisi oleh responden bahwa dari 9 responden perekam medis dan 18 responden staf ruang rawat inap yang memberi pernyataan bahwa tata kelola SIM-RS dalam pencegahan ketidaklengkapan sensus harian rawat inap di Rumah Sakit Tingkat III 03.06.01 Ciremai Cirebon sudah sesuai dan 9 responden yang memberi pernyataan tata kelola SIM-RS dalam pencegahan ketidaklengkapan sensus harian rawat inap di Rumah Sakit Tingkat III 03.06.01 Ciremai Cirebon kurang sesuai adalah terdiri dari 8 responden perekam medis dan 1 responden staf ruang rawat inap.

Tata kelola SIM-RS dalam pencegahan ketidaklengkapan sensus harian rawat inap yang disebut kategori sesuai berarti tata kelola SIM-RS yang dapat menerapkan fungsi-fungsi manajemen SIM-RS dalam pengembangan sistem informasi manajemen rumah sakit sebagai upaya dalam pencegahan ketidaklengkapan sensus harian rawat inap agar dapat memenuhi kriteria standar kelengkapan data-data rekam medis yakni $100 \%$ terisi pada semua item atau poin di dalam formulir sensus harian rawat inap.

Tata kelola SIM-RS didefinisikan sebagai sekumpulan manajemen, perencanaan dan pelaporan kinerja serta proses peninjauan terkait keputusan, yang menetapkan kontrol dalam kinerja penyelenggaran SIM-RS, pelayanan serta perubahan atau otoritas baru yang berkaitan kepatuhan peraturan, hukum serta kebijakan rumah sakit (Fahmi, 2016).

Tata kelola SIM-RS dalam pencegahan ketidaklengkapan sensus harian rumah sakit adalah merupakan upaya yang dilakukan instalasi SIM-RS dalam pembuatan sensus harian rawat inap yang masih menggunakan media kertas menjadi berbasis aplikasi atau website sebagai upaya mencegah terjadinya ketidaklengkapan dan keterlambatan dalam pengisian sensus harian rawat inap di rumah sakit.

2. Struktur organisasi instalasi SIM-RS dalam pelaksanaan sensus harian rawat inap di Rumah Sakit Tingkat III 03.06.01 Ciremai Cirebon

Hasil data analisa pada indikator struktur organisasi instalasi SIM-RS dalam pelaksanaan sensus harian rawat inap di Rumah Sakit Tingkat III 03.06.01 Ciremai Cirebon berdasarkan tabel 2 yang didapatkan 34 responden $(94,4 \%)$ menyatakan bahwa struktur organisasi instalasi SIM-RS sudah sesuai. Berdasarkan hasil penelitian ini dan setelah peneliti mengamati data hasil kuesioner pada indikator struktur organisasi instalasi SIM- RS dalam pelaksanaan sensus harian rawat inap yang telah diisi oleh responden terdapat 16 responden perekam medis dan 18 responden staf ruang rawat inap yang memberi pernyataan bahwa struktur organisasi instalasi SIM-RS dalam pelaksanaan sensus harian rawat inap sesuai dan terdapat pernyataan bahwa struktur organisasi instalasi SIM-RS dalam pelaksanaan sensus harian rawat inap masih kurang 
sesuai terdiri dari 1 responden perekam medis dan 1 responden staf ruang rawat inap.

Berdasarkan Peraturan Menteri Kesehatan RI nomor 82 tahun 2013, dikatakan bahwa Tata kelola SIM-RS terdapat struktur organisasi pada instalasi SIM-RS yang terdiri dari kepala dan staf instalasi SIMRS. Organisasi di dalam instalasi SIM-RS terdapat pimpinan dan staf unit kerja SIM-RS yang memiliki tugas pokok masing-masing dalam penyelenggaraan SIM-RS yang meliputi kepala instalasi dan staf koordinator pengembang SIM-RS.

Menurut Fahmi (2016), dikatakan bahwa struktur organisasi dalam instalasi SIM-RS memiliki peran penting dalam penyelenggaraan SIM-RS, dapat dikatakan bahwa sukses atau tidaknya penerapan SIMRS tergantung dari kebijakan dan dukungan yang diberikan dari pimpinan atau menajemen dalam sebuah organisasi instalasi SIM-RS.

Kepala instalasi SIM-RS memiliki tanggung jawab meliputi membuat dan menjalankan perencanaan kegiatan penerapan dan pengembangan SIM-RS di rumah sakit, menjalin koordinasi dan kerjasama dengan manajemen rumah sakit, unit rekam medis, dan instalasi pelayanan dalam penerapan dan pengembangan SIM- RS, menerima dan menangani keluhan dari masing-masing instalasi pelayanan kesehatan di rumah sakit yang berhubungan dengan sistem informasi manajemen rawat jalan, rawat inap, dan IGD, dan melakukan identifikasi, estimasi dan evaluasi terhadap penerapan dan pengembangan SIMRS (Fahmi, 2016).

Struktur organisasi instalasi SIM-RS memiliki peranan penting dalam pembuatan dan pengembangan SIM-RS rumah sakit yang termasuk pada pembuatan sensus harian rawat inap berbasis aplikasi atau website sebagai upaya dalam pelaksanaan sensus harian rawat inap rumah sakit yang dapat mencegah terjadinya ketidaklengkapan data dan keterlambatan pengisian sensus harian rawat inap, peran koordinasi kepala instalasi dan staf instalasi SIM-RS dengan unit rekam medis dan unit rawat inap dalam perencanaan dan implementasi sensus harian rawat inap berbasis aplikasi atau website serta menentukan tenaga kesehatan yang ditunjuk memiliki hak akses atau pengguna (admin) SIM-RS sensus harian rawat inap. Perawat atau bidan dan petugas rekapitulasi sensus harian rumah sakit merupakan tenaga kesehatan pengelola data sensus harian rawat inap yang dapat memiliki hak akses untuk menggunakan SIM-RS sensus harian rawat inap.

3. Sumber daya manusia instalasi SIM-RS dalam pelaksanaan sensus harian rawat inap di Rumah Sakit Tingkat III 03.06.01 Ciremai Cirebon

Berdasarkan hasil penelitian pada tabel 3 dapat dikatakan secara umum responden memberikan pernyataan bahwa sumber daya manusia instalasi SIMRS dalam pelaksanaan sensus harian rawat inap di Rumah Sakit Tingkat III 03.06.01 Ciremai Cirebon dalam kategori sesuai, hal ini terdapat pada data hasil penelitian yang didapatkan dari 31 responden $(86,1 \%)$ yang menyatakan bahwa sumber daya manusia instalasi SIM-RS dalam pelaksanaan sensus harian rawat inap sudah sesuai. Berdasarkan pengamatan peneliti terhadap kuesioner yang telah diisi oleh responden bahwa terdapat 15 responden dari perekam medis dan 16 responden dari staf ruang rawat inap yang memberi pernyataan sumber daya manusia instalasi SIM-RS dalam pelaksanaan sensus harian rawat inap di Rumah Sakit Tingkat III 03.06.01 Ciremai Cirebon sudah sesuai dan terdapat pernyataan bahwa sumber daya manusia instalasi SIM-RS dalam pelaksanaan sensus harian rawat inap di Rumah Sakit Tingkat III 03.06.01 Ciremai Cirebon masih kurang sesuai terdiri dari 2 responden perekam medis dan 3 responden staf ruang rawat inap. Hasil penelitian pada indikator sumber daya manusia SIM-RS dalam pelaksanaan sensus harian rawat inap di Rumah Sakit Tingkat III 03.06.01 Ciremai Cirebon sesuai dengan upaya 
komunikasi dan koordinasi antara pengguna (admin)

SIM- RS pada setiap ruang rawat inap dengan staf koordinator instalasi SIM-RS terhadap perbaikan kendala dan gangguan pada SIM- RS dan pemeliharaan sistem pada unit komputer dan jaringan di ruang rawat inap dan ruang rekam medis oleh staf hardware dan maintanace jaringan.

Berdasarkan Permenkes No.82 tahun 2013, dikatakan bahwa sumber daya manusia dalam instalasi unit kerja SIM-RS terdiri dari staf yang memiliki kualifikasi dalam bidang staf analis system, staf programmer, staf hardware, dan staff maintanance jaringan.

Menurut hasil penelitian Indra (2013) tentang evaluasi sistem informasi manajemen rumah sakit (SIM-RS) RSUD Brebes dalam kesiapan penerapan sistem informasi rumah sakit (SIRS) online Kemenkes RI, dikatakan bahwa seorang pimpinanan instalasi SIM-RS rumah sakit harus memperhakan Sumber Daya Manusia untuk meningkatkan mutu pelayanan rumah sakit dalam pelaksanaan SIM-RS di rumah sakit. Penelitian ini sejalan dengan penelitian Indra (2013) bahwa instalasi SIM-RS di Rumah Sakit Tingkat III 03.06.01 Ciremai Cirebon memiliki staf analis system, staf programmer, staf hardware, dan staff maintanance jaringan dan pengguna (admin) SIMRS pada setiap ruang rawat inap.

Kepala instalasi SIM-RS dan staf yang meliputi staf analis system, staf programmer, staf hardware, dan staf maintanance jaringan mempunyai peran dalam pembuatan SIM-RS sensus harian rawat inap, melakukan sosialisasi dan pelatihan kepada tenaga kesehatan yang diberi tugas untuk menjadi pengguna (admin) SIM-RS sensus harian rawat inap. Tenaga kesehatan yang yang diberi tugas menjadi pengguna (admin) SIM-RS sensus harian rawat inap adalah perawat dan bidan pelaksana sensus harian rawat inap di setiap ruang rawat inap rumah sakit dan perekam medis yang mengelola data sensus harian rawat inap untuk kebutuhan statistik rumah sakit.

Dalam penyelenggaraan SIM-RS perlu dilakukan pembinaan dan pengawasan sesuai dengan uraian tugas yang diberikan kepada pengguna SIM-RS berupa advokasi dan sosialisasi, pendidikan dan pelatihan, bimbingan teknis, dan pemantauan dan evaluasi oleh instalasi SIM-RS dan direktur rumah sakit yang ditujukan untuk meningkatkan mutu penyelenggaraan

SIM-RS dan mengembangkan penyelenggaraan SIM- RS. Alur kerja instalasi SIM-RS dalam pembuatan SIM-RS sensus harian rawat inap dimulai dari koordinasi dan diskusi staf instalasi SIM-RS dengan instalasi rekam medis dan instalasi rawat inap terhadap analisis masalah pada pelaksanaan sensus harian rawat inap, perencanaan pembuatan SIM-RS sensus harian rawat inap, uji coba SIM-RS sensus harian rawat inap, implementasi penggunaan SIM-RS sensus harian rawat inap serta dilakukan monitoring dan evaluasi.

4. Kerangka kerja instalasi SIM-RS dalam pelaksanaan sensus harian rawat inap di Rumah Sakit Tingkat III 03.06.01 Ciremai Cirebon

Hasil data analisa pada indikator kerangka kerja instalasi SIM-RS dalam pelaksanaan sensus harian rawat inap di Rumah Sakit Tingkat III 03.06.01 Ciremai Cirebon berdasarkan tabel 4 diperoleh 15 responden $(41,7 \%)$ menyatakan bahwa kerangka kerja instalasi SIM-RS dalam pelaksanaan sensus harian rawat inap sudah sesuai, 12 responden $(33,3 \%)$ menyatakan bahwa kerangka kerja instalasi SIM-RS dalam pelaksanaan sensus harian rawat inap masih kurang sesuai, dan menyatakan bahwa kerangka kerja instalasi SIM-RS dalam pelaksanaan sensus harian rawat inap masih tidak sesuai yaitu 9 responden $(25,0 \%)$. Berdasarkan pengamatan peneliti terhadap kuesioner yang telah diisi oleh responden bahwa terdapat 2 responden dari perekam medis dan 13 responden dari staf ruang rawat inap yang memberi 
pernyataan sumber kerangka kerja instalasi SIM-RS dalam pelaksanaan sensus harian rawat inap di Rumah Sakit Tingkat III 03.06.01 Ciremai Cirebon sudah sesuai, pernyataan bahwa kerangka kerja instalasi SIMRS dalam pelaksanaan sensus harian rawat inap di Rumah Sakit Tingkat III 03.06.01 Ciremai Cirebon masih kurang sesuai terdiri dari 7 responden perekam medis dan 4 responden staf ruang rawat inap dan terdiri dari terdiri dari 7 responden perekam medis dan 2 responden staf ruang rawat inap yang memberi pernyataan bahwa kerangka kerja instalasi SIM-RS dalam pelaksanaan sensus harian rawat inap di Rumah Sakit Tingkat III 03.06.01 Ciremai Cirebon tidak sesuai. Hasil penelitian ini sesuai dengan dengan uraian tugas instalasi SIM-RS yakni kegiatan sosialisasi dan pelatihan penggunaan SIM-RS belum dilakukan secara menyeluruh serta evaluasi terhadap pembuatan dan perbaikan SIM-RS.

Berdasarkan Permenkes No.82 tahun 2013, kerangka kerja tata kelola instalasi SIM-RS di rekomendasikan menggunakan kerangka kerja best practice Control Objective for Information and related Technology (COBIT). COBIT adalah suatu panduan standar pelaksanaan manajemen teknologi informasi perusahaan atau instansi dikeluarkan oleh Information Technology (IT) Governance Institute yang merupakan bagian dari Systems Audit and Control Association (ICASA) (Fahmi, 2016).

\section{KESIMPULAN}

Berdasarkan hasil penelitian tentang "Tata Kelola SIM-RS Dalam Pencegahan Ketidaklengkapan Sensus Harian Rawat Inap di Rumah Sakit Tingakt III
06.03.01 Ciremai Cirebon" dapat disusun kesimpulan sebagai berikut :

a. Tata kelola SIM-RS dalam pencegahan ketidaklengkapan sensus harian rawat inap yang sesuai adalah $27(75,0 \%)$.

b. Struktur organisasi instalasi SIM-RS dalam pelaksanaan sensus harian rawat inap yang sesuai yaitu $34(94,4 \%)$.

c. Sumber daya manusia instalasi SIM-RS dalam pelaksanaan sensus harian rawat inap yang sesuai adalah $31(86,1 \%)$.

d. Kerangka kerja instalasi SIM-RS dalam pelaksanaan sensus harian rawat inap terdapat $15(41,7 \%)$ yang sesuai

\section{REFERENSI}

Fahmi H. 2016. Sistem Informasi Kesehatan. Gosyen Publishing. Yogyakarta.

Hosizah dan Maryati, Y. 2018. Sistem Informasi Kesehatan II : Statistik Pelayanan Kesehatan. Kemenkes RI. Jakarta. http://bppsdmk.kemkes.go.id/pusdiks dmk/wpcontent/uploads/2018/09/Sist em-informasikesehatan-II_SC.pdf. Diakses pada 27 Februari 2021.

Komisi Akreditasi Rumah Sakit. 2017. Standar Nasional Akreditasi Rumah Sakit (SNARS) edisi 1, Jakarta : KARS.

http://web90.opencloud.dssdi.ugm.ac

.id/wpcontent/uploads/sites/644/2018

105/SNARS-Edisi-1.pdf .__ Diakses pada 15 Maret 2021.

Peraturan Menteri Kesehatan RI No.82 Tahun 2013 tentang Sistem Informasi Manajemen Rumah Sakit.

Suhamad. 2015. Tinjauan Kelengkapan Pengisian Sensus Harian Rawat Inap Di Ruang Infeksi Departemen Ilmu Kesehatan Anak Rumah Sakit Umum Pusat Nasional Dr Cipto Mangunkusumo Jakarta. https://bit.ly/3otNXdo. $\quad$ Diakses tanggal 28 Januari 2021 